\title{
Estimating the Ultimate Recoverable Reserves of the Paris Basin, France
}

\author{
J. Wendebourg ${ }^{1}$ and C. Lamiraux ${ }^{2}$ \\ 1 Institut français du pétrole, 1 et 4, avenue de Bois-Préau, 92852 Rueil-M almaison Cedex - France \\ 2 Direction générale de l'énergie et des matière premières (DG EM P), 41, boulevard Vincent Auriol, 75703 Paris Cedex 13 - France \\ e-mail: johannes.wendebourg@ifp.fr
}

\begin{abstract}
Résumé - Estimation des réserves ultimes récupérables du Bassin parisien, France — Le Bassin parisien est un bassin mature en exploration pétrolière. Pas moins de 800 puits exploratoires ont été forés pendant les 40 dernières années et 52 champs de pétrole ont été découverts : 33,4 Mt de pétrole ont été produits jusqu'en 2000. Le potentiel du Bassin parisien est estimé à l'aide de méthodes statistiques. La taille moyenne d'un champ est de $100000 \mathrm{t}$ avec une probabilité de $5 \%$ de trouver un champ de plus de 2,5 Mt. Les réserves ultimes récupérables étaient de 15 Mt en 1986, 29 Mt en 1991 et 46 Mt en 1996. Aujourd'hui, il y a une probabilité de $5 \%$ de trouver un champ de plus de $4 \mathrm{Mt}$ dans les grès du Dogger ou du Keuper. Le taux de succès augmente de 1/66 dans la formation du Néocomien, le réservoir le moins profond, à $1 / 8$ dans le Keuper, le réservoir le plus profond et le plus récemment foré. L'analyse présentée s'appuie sur des données de production et ne prend pas en compte une production supplémentaire éventuelle grâce à des méthodes de récupération assistée ou grâce à des découvertes basées sur de nouveaux concepts d'exploration, susceptibles d'augmenter les réserves de façon significative, bien au-delà des chiffres présentés comme cela est démontré par l'analyse de la courbe crémière.
\end{abstract}

\begin{abstract}
Estimating the Ultimate Recoverable Reserves of the Paris Basin, France - The Paris Basin is a mature basin from an exploration point of view. More than 800 exploration wells have been drilled over the last 40 years and 52 fields have been discovered from which 33.4 Mt of petroleum have been produced by the end 2000. Based on past production data, the future exploration and production potential of the Paris Basin is estimated using classical statistical methods. The mean size of a field in the Paris Basin is about $100000 t$ with a 5\% chance of a field whose size is greater than $2.5 \mathrm{Mt}$. The ultimate recoverable reserves based on the creaming curve analysis were about 15 Mt in 1986, 29 Mt in 1991 and 46 Mt in 1996. At present, there is a 5\% chance of finding a field in the Dogger and Keuper formations that is bigger than $4 \mathrm{Mt}$. The drilling success ratio increases from 1/66 for the shallowest, the Cretaceous Neocomian formation to 1/8 in the deepest and latest to be drilled Triassic Keuper formation. The data analysis presented in the paper is based on known production data which do not take into account additional production gained by enhanced recovery methods or additional reserves added by discoveries based on new plays, that however may significantly increase reserves beyond the numbers presented here as the creaming curve analysis has shown.
\end{abstract}




\section{IN TRO DUCTIO N}

The Paris Basin is one of the major petroleum production basins of continental Europe and the premier petroleum province of France (Weaver et al., 1988). More than 800 exploration wells have been drilled over the last 40 years and 52 fields have been discovered from which $33.4 \mathrm{Mt}$ of petroleum have been produced by the end 2000 . The Paris Basin is a good example of a mature petroleum basin where exploration is polyphase following technological progress and favorable economics and where production is presently in decline. In this paper, we will examine, based on past production data, the future exploration and production potential of this mature basin using classical statistical methods (Harbaugh et al., 1995). This approach does not try to develop new exploration plays based on new geophysical or geochemical data, or identify enhanced production possibilities of existing producing fields. It is based on the assumption that a sedimentary basin is a closed petroleum system and that past production data can be used to infer future exploration potential, particularly in a mature basin such as the Paris Basin.

The Paris Basin is an intracratonic basin located in Northern France, with an extension of about $500 \mathrm{~km}$ eastwest and $300 \mathrm{~km}$ north-south, approximately coinciding with the drainage basin of the Seine river (Fig. 1). It is a saucershaped basin with a maximum thickness of sediments of more than $3 \mathrm{~km}$. The basin is slightly asymetric due to Tertiary erosion and uplift in its Eastern part (Fig. 2). The stratigraphic column in the basin center includes some $150 \mathrm{~m}$ of Tertiary, about $1000 \mathrm{~m}$ of Cretaceous, some $1500 \mathrm{~m}$ of Jurassic and some $500 \mathrm{~m}$ of Permo-Triassic sediments (Fig. 3). The fault pattern of the basin is governed by the Premesozoic basement with NW-SE striking fault zones of Hercynian heritage. The principal oil-bearing formations are the Middle Jurassic (Bathonian) Dogger carbonates, the Upper Triassic Keuper sandstones, but also the Lower Cretaceous Neocomian sandstones and the Upper Triassic Rhaetian sandstones (Lamiraux and Mascle, 1998). The principal source rocks for the oils in the Paris Basin are the Lower Jurassic Toarcian black shales (schistes carton). They

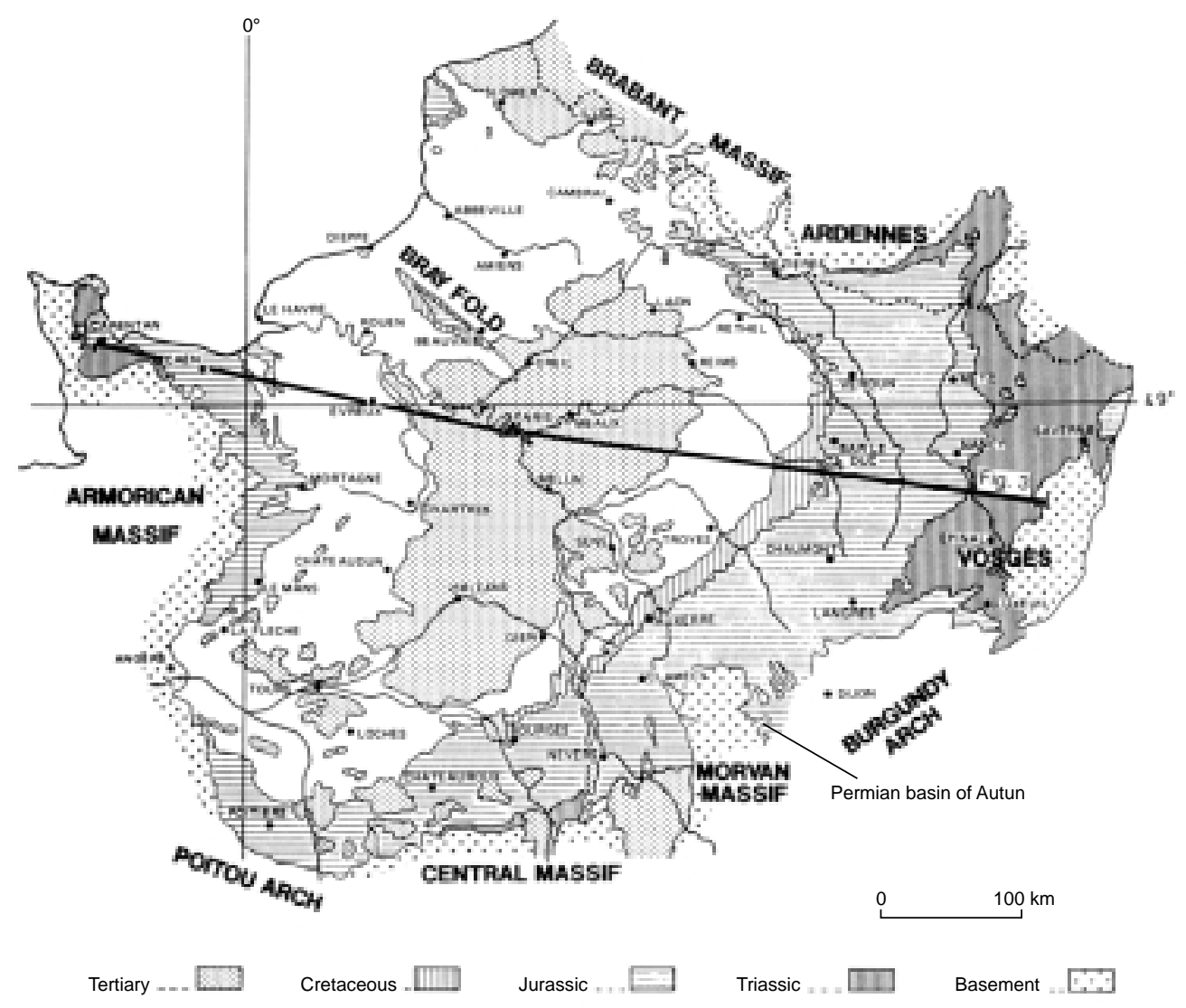

Figure 1

Location map (from Perrodon and Zabek, 1991). 


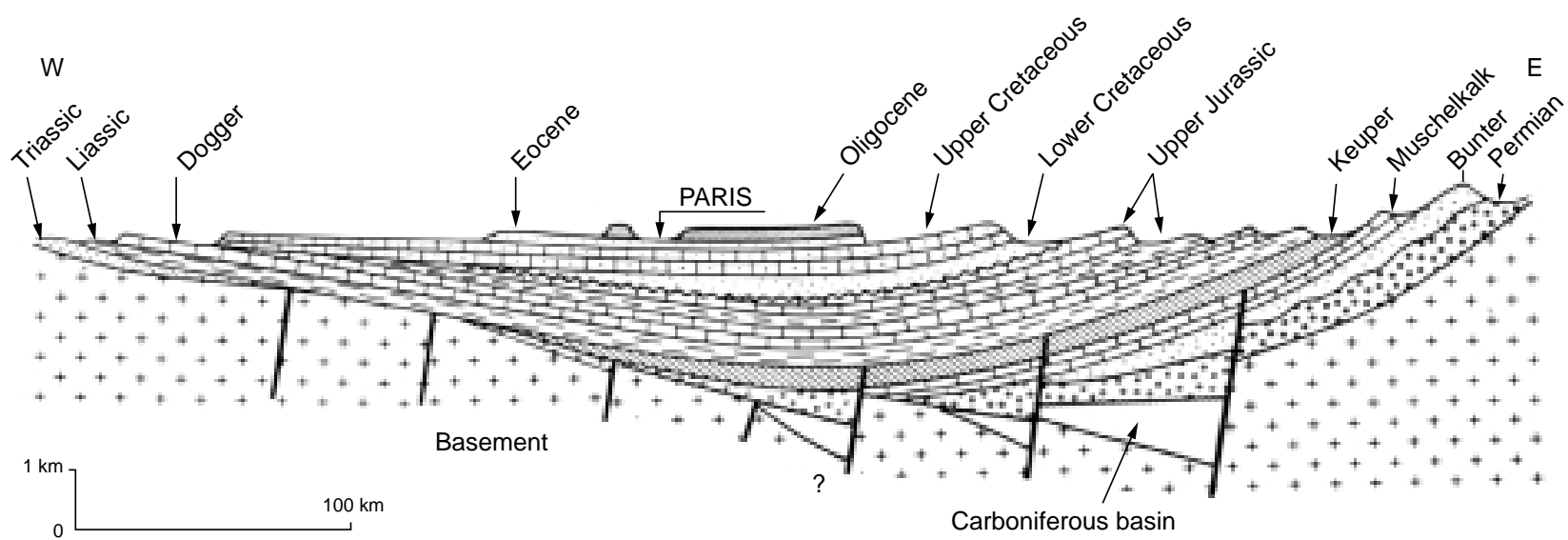

Figure 2

Cross section (from Perrodon and Zabek, 1991).

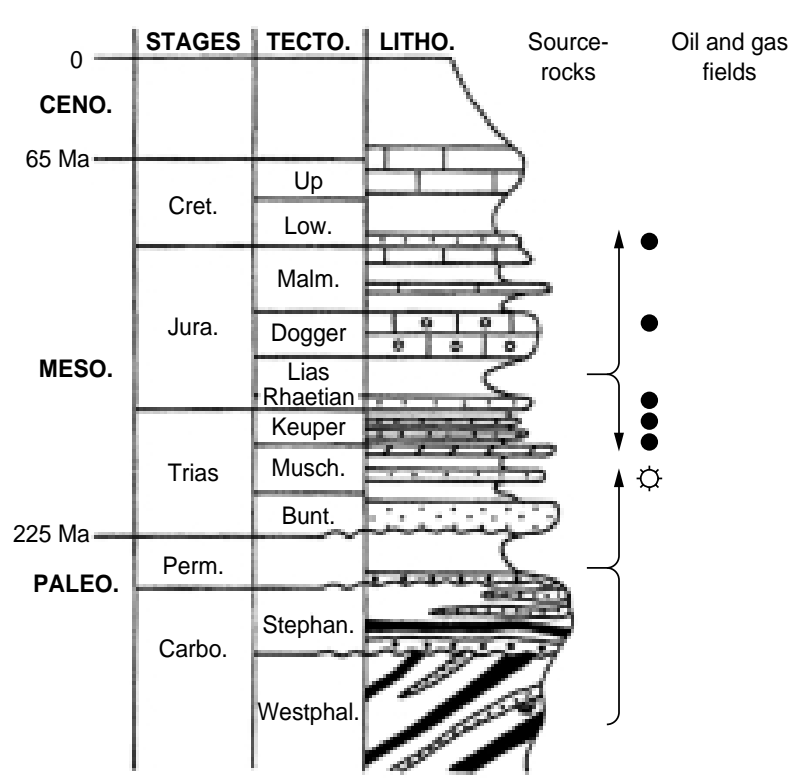

Figure 3

Chronostratigraphic log (from Lamiraux and Mascle, 1998).

are presently in the oil window in the center of the basin (Gaulier and Burrus, 1994). Oil migration occurred vertically into the overlying Middle Jurassic carbonates and into the underlying Triassic sandstones, and then laterally within the reservoir formations.

Petroleum exploration in the Paris Basin started in the 1950s (Fig. 4) with a present-day maximum density of wells in the central part just east of Paris (Fig. 5). First discoveries were made in the Cretaceous Neocomian sandstones and in the Jurassic Dogger carbonates (Fig. 6). The first exploration peak was reached in the 1960s followed by a

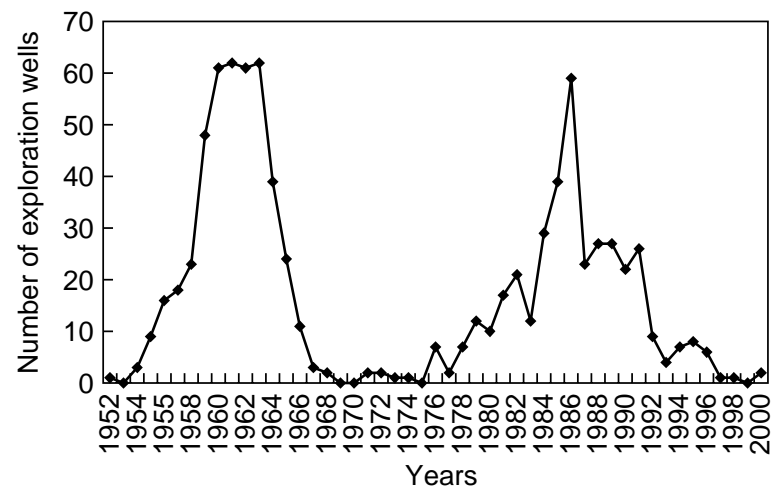

Figure 4

Total number of exploration wells drilled yearly in the Paris Basin.

pause in the 1970s. In the 1980s, exploration experienced a revival with new discoveries in Triassic Keuper sediments, the most spectacular of which was the discovery of the Chaunoy field in 1982 which by the end 2000 has produced almost $9.5 \mathrm{Mt}$ of petroleum. Figures 7 and 8 show the location and extension of all fields in the central part of the basin having produced from the Dogger and Keuper reservoirs. Cumulative petroleum production as a function of year of discovery reflects this evolution (Fig. 6). Discoveries in the 1960s are fields that had produced more than $1 \mathrm{Mt}$ of petroleum in 2000. After a low in the 1970s, petroleum production picks up in the 1980s. In the 1990s, several discoveries of small to intermediate size have been made. The production curve of the entire basin is dominated by the two biggest fields, Villeperdue and Chaunoy, both 


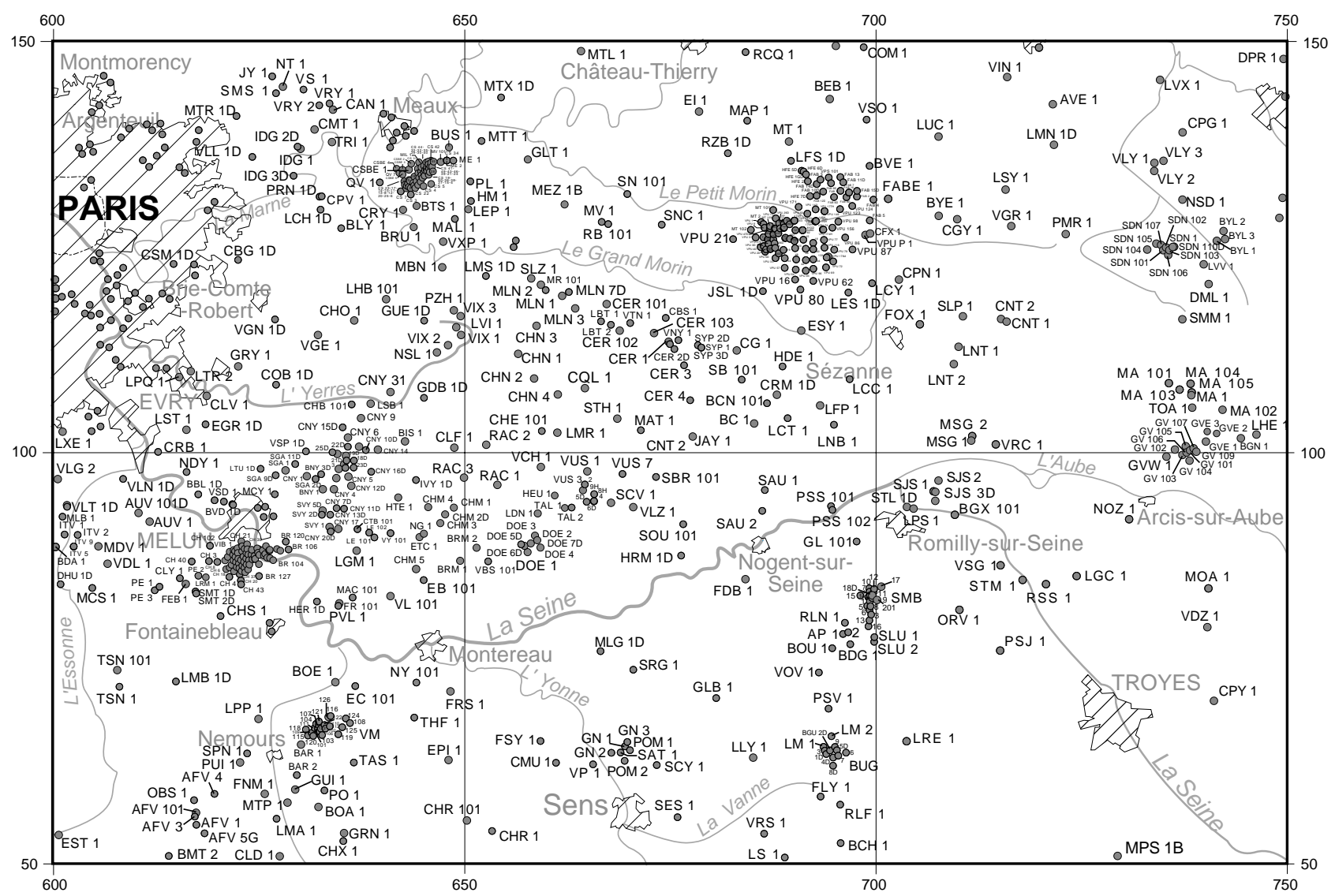

Figure 5

Location map of exploration wells drilled into Middle Jurassic Dogger formation in central part of Paris Basin (includes development wells of some fields).

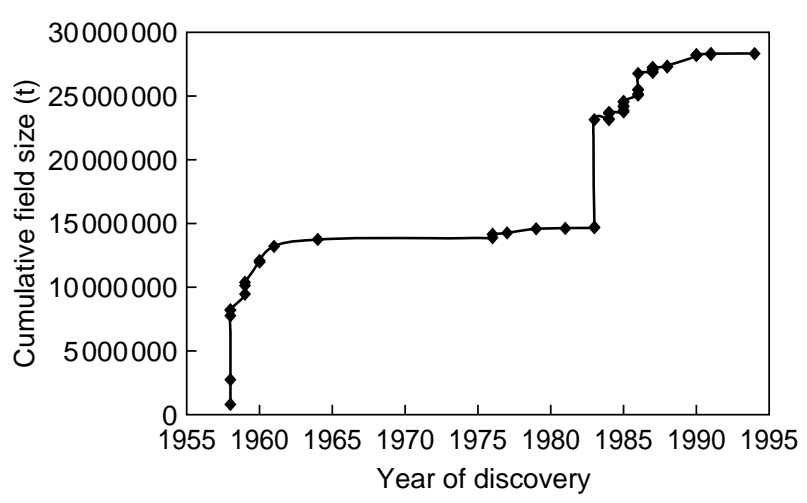

Figure 6

Field size versus discovery year in Paris Basin.

coming on production in the 1980 s, and their subsequent decline, masking the additional production of all other fields.

\section{PRO DUCTION HISTORY OF THE PARIS BASIN}

Figure 9 displays petroleum production through time in the Paris Basin separated by producing formation. The data consist of yearly production from production start to end 2000. Production is shown as liquid petroleum in all cases. In the Paris Basin, only $7 \%$ of the total production is gas of which $63 \%$ come from a single field, the Trois-Fontaines field producing from the Middle Triassic Muschelkalk formation. $30 \%$ of gas production consists of coalbed methane from the Poisonnière field.

Four main oil producing horizons are identified : the Cretaceous Neocomian sandstones, the Middle-Jurassic Dogger sandstones, the Upper Triassic Rhaetian marine sandstones and the Upper Triassic Keuper Donnemarie and Chaunoy sandstones. The Dogger and Keuper sandstones are by far the main producing horizons in the Paris Basin with each about $40 \%$ of total production. 


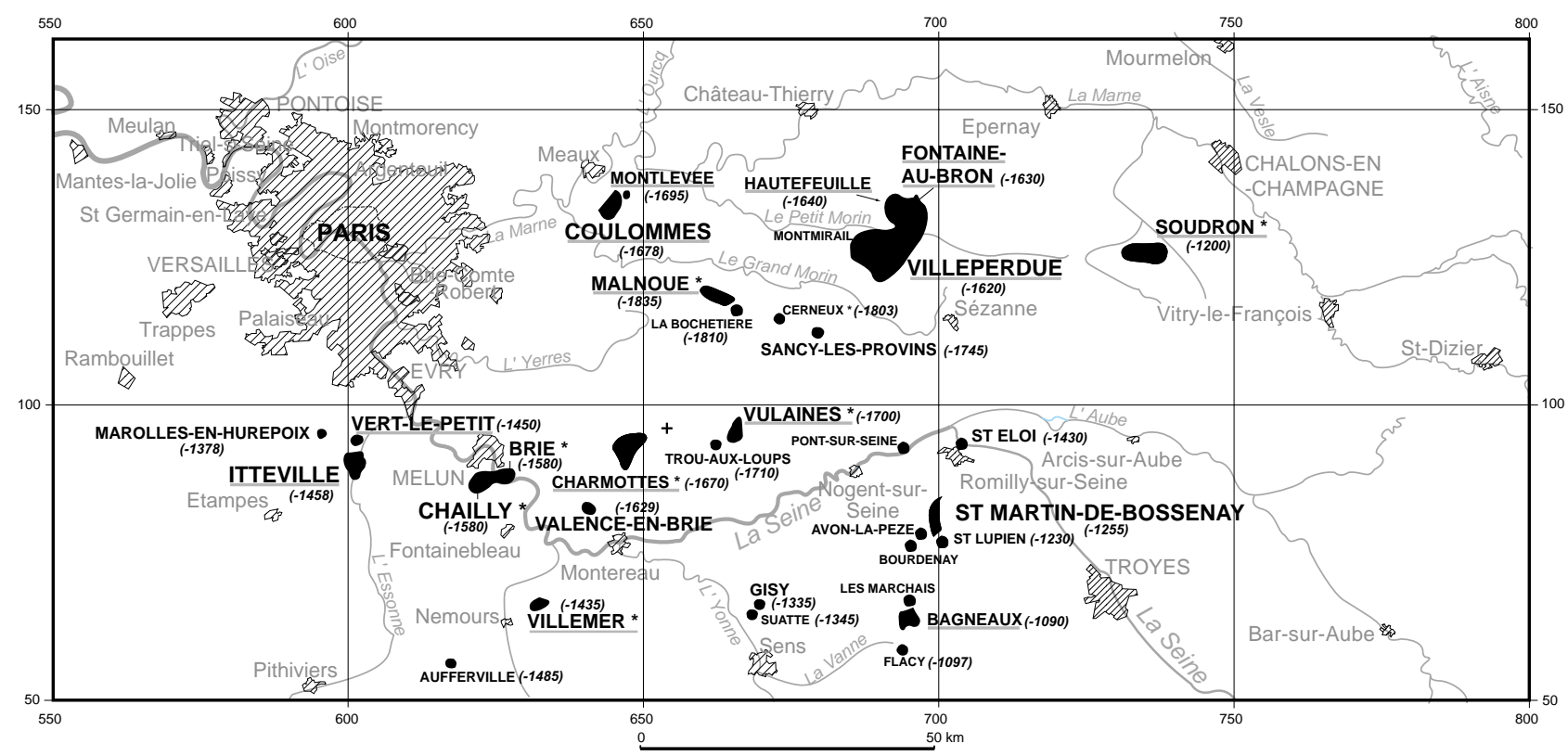

Figure 7

Location map of oil fields of central part of Paris Basin that produce (underlined) or have produced from Middle Jurassic Dogger formation. Number next to name indicates subsea depth of top of reservoir $(\mathrm{m})$.

(*) indicates that field also produces from underlying Keuper formation.

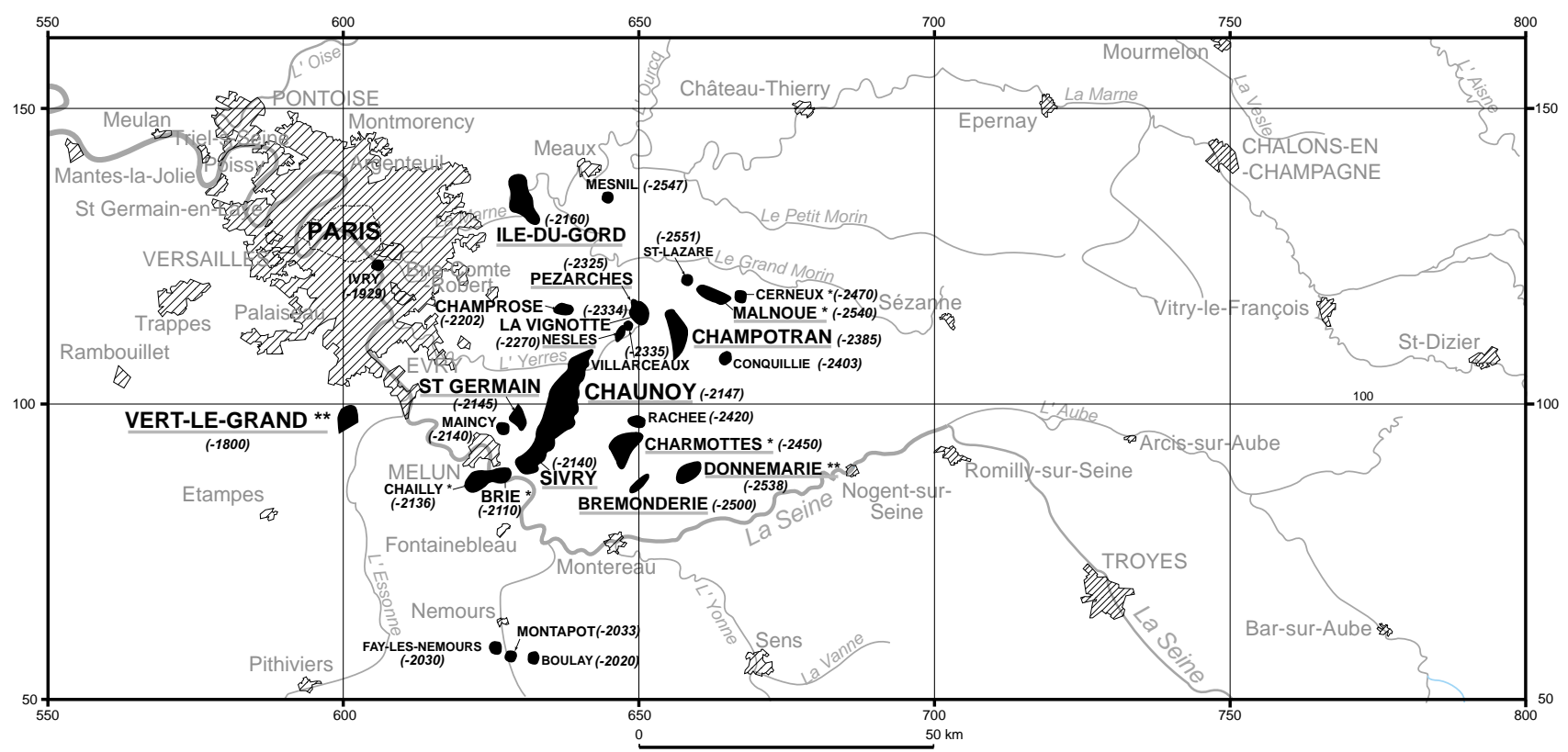

Figure 8

Location map of oil fields of central part of Paris Basin that produce (underlined) or have produced from Upper Triassic Keuper formation. Number next to name indicates subsea depth of top of reservoir $(\mathrm{m})$.

(*) indicates that field also produces from overlying Dogger formation. 


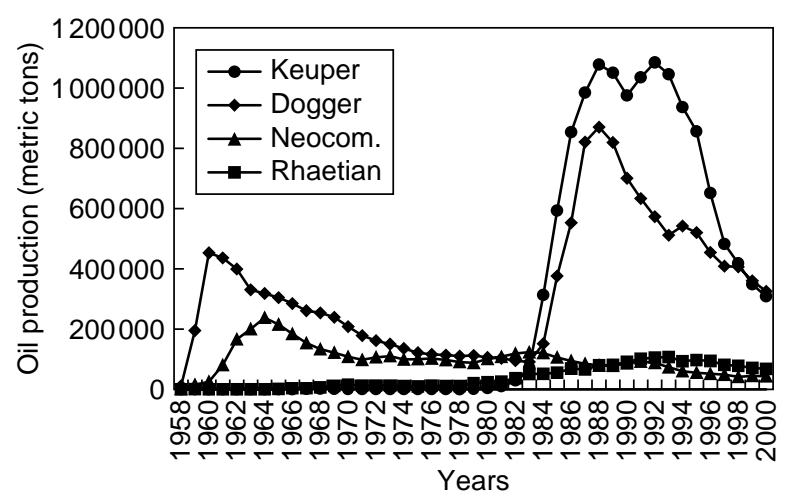

Figure 9

Yearly total production in Paris Basin.

The Neocomian is the shallowest reservoir which also was discovered first. The Neocomian yields only small fields where production is rarely greater than 100000 t/year. Most fields producing from the Dogger formation have been discovered in the early years of exploration in the Paris Basin. Villeperdue is the biggest Dogger field with a yearly production of almost $1 \mathrm{Mt}$ in the 1980s but also in strong decline since the 1990s. The Upper Triassic Rhaetian fields have all very small sizes. The Rhaetian play had been discovered shortly before the slightly deeper Keuper play. The Keuper play is the most important play in the Paris Basin and has been explored since the early 1980s. The Keuper production is dominated by the Chaunoy field which has been particularly high (more than 700000 t/year over a period of several years).

\section{FIELD SIZE ESTIMATIO N}

Decline curves have been extrapolated beyond 2000 to determine the ultimate cumulative production assuming no enhanced recovery. Integrating all production curves over the next 10 years (Fig. 10), ultimate production is estimated to be $37.2 \mathrm{Mt}$ of which nearly $90 \%$ have already been

TABLE 1

Reserves and production statistics of Paris Basin (Mt)

\begin{tabular}{l|c|c|c}
\hline & $\begin{array}{c}\text { Production } \\
\text { until } 2000\end{array}$ & $\begin{array}{c}\text { Ultimate } \\
\text { production } \\
\text { from existing } \\
\text { fields* }\end{array}$ & $\begin{array}{c}\text { Ultimate } \\
\text { recoverable } \\
\text { reserves without } \\
\text { new plays }\end{array}$ \\
\hline Neocomian & $4.23(13 \%)$ & $4.48(12 \%)$ & 5.52 \\
Dogger & $14.31(43 \%)$ & $16.37(44 \%)$ & 20.24 \\
Rhaetian & $1.68(5 \%)$ & $2.12(6 \%)$ & 2.84 \\
Keuper & $13.14(39 \%)$ & $14.24(38 \%)$ & 18.40 \\
\hline Total & $33.41(100 \%)$ & $37.21(100 \%)$ & 47.00 \\
\hline
\end{tabular}

* Using decline functions based on production data from 1995-2000 (Fig. 10).

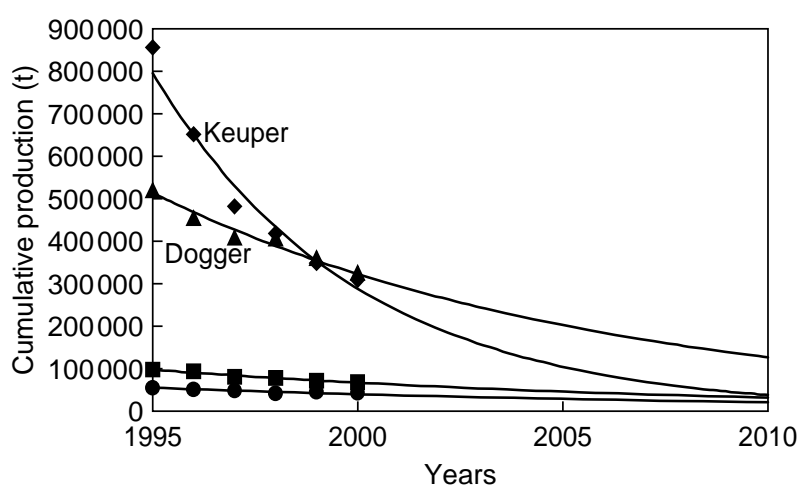

$$
\begin{array}{ll}
\text { Neocomian: } & \mathrm{R}=2 \mathrm{E}+60 \operatorname{EXP}\left(-0.0642^{*} \text { year }\right), \mathrm{R}^{2}=0.9917 \\
\text { Dogger: } & \mathrm{R}=2 \mathrm{E}+86 \operatorname{EXP}\left(-0.093^{*} \text { year }\right), \mathrm{R}^{2}=0.9987 \\
\text { Rhetian: } & \mathrm{R}=9 \mathrm{E}+69 \operatorname{EXP}\left(-0.075^{*} \text { year }\right), \mathrm{R}^{2}=0.9987 \\
\text { Keuper: } & \mathrm{R}=4 \mathrm{E}+118 \operatorname{EXP}\left(-0.2028^{*} \text { year }\right), \mathrm{R}^{2}=0.9989
\end{array}
$$

Figure 10

Projected production decline of existing fields in Paris Basin.

produced by the end 2000 (Table 1). Using the ultimate production of each field, the field size distribution of a basin can be plotted (Fig. 11) from which probabilities can be estimated for a given field size. In a petroleum producing sedimentary basin, such a distribution is usually lognormal plotting along a straight line on lognormal paper (Harbaugh et al., 1995). This is also the case in the Paris Basin (Fig. 12). The mean size of a field in the Paris Basin is therefore about $100000 \mathrm{t}$ (50\% probability) with a 5\% chance of a field whose size is greater than $2.5 \mathrm{Mt}$.

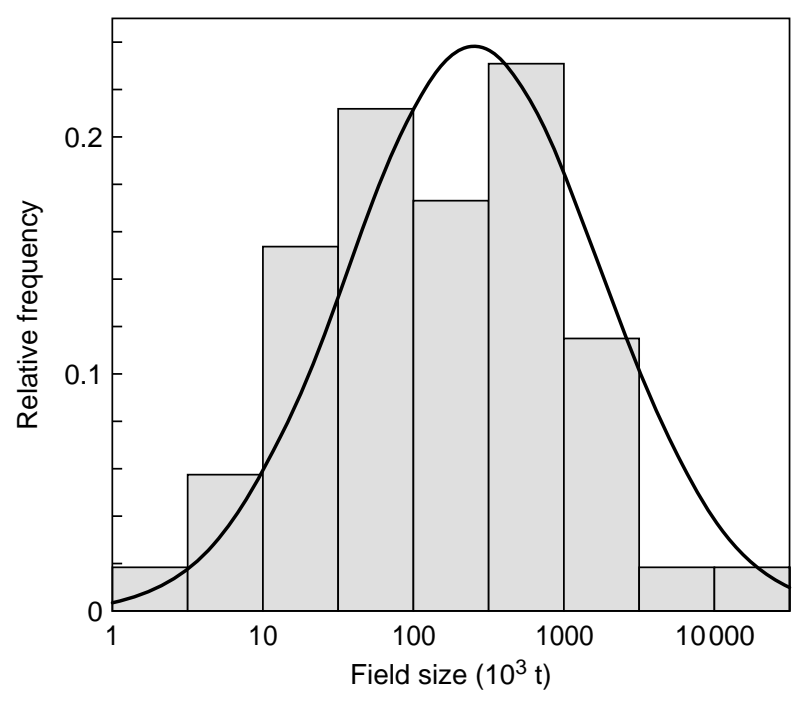

Figure 11

Field size distribution of Paris Basin as histogram. 


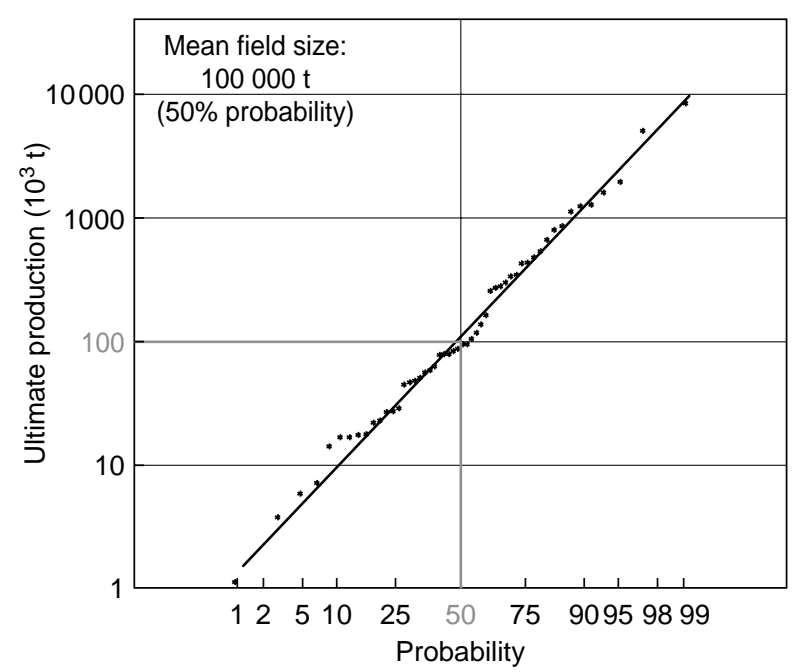

Figure 12

Field size distribution of Paris Basin on lognormal paper.

\subsection{By G lobal Statistics}

In petroleum-bearing basins that are in a mature exploration stage, a curve plotting cumulative number of exploration wells against cumulative production (also called creaming curve) tends asymptotically towards a single value, the ultimate recoverable reserves of the basin (Fig. 13). In the Paris Basin, this value is not constant in time. It is about $15 \mathrm{Mt}$ in 1986, $29 \mathrm{Mt}$ in 1991 and $46 \mathrm{Mt}$ in 1996. This rather empirical and graphical method introduces uncertainties with respect to the extrapolated reserves but gives a good idea about the reserves that cannot be exceeded significantly except by discovering different plays in the future. For this reason, reserve estimates are different in the past. For example, the Triassic discoveries in the early 1980s have significantly changed the form of the creaming curve and estimated reserves have trippled from 15 to $46 \mathrm{Mt}$.

\subsection{By Year of Discovery}

Figure 14 displays the same data as Figure 12 with the difference that field size is separated by year of discovery. Fields discovered in the 1960s have been separated from fields discovered between 1976 and 1986 and from those discovered between 1986 and 1996. This analysis shows that fields discovered in the 1960s have also been biggest, with a mean size of $230000 \mathrm{t}$ and a $5 \%$ probability of more than $8 \mathrm{Mt}$. Later, this trend is towards smaller fields which is typical for petroleum-bearing sedimentary basins where the biggest fields are usually discovered first (Harbaugh et al., 1995). In the 1980s and 1990s, mean field size in the Paris Basin decreased to about 100000 t. Between 1976-1986, the slope of the lognormal distribution is significantly higher,

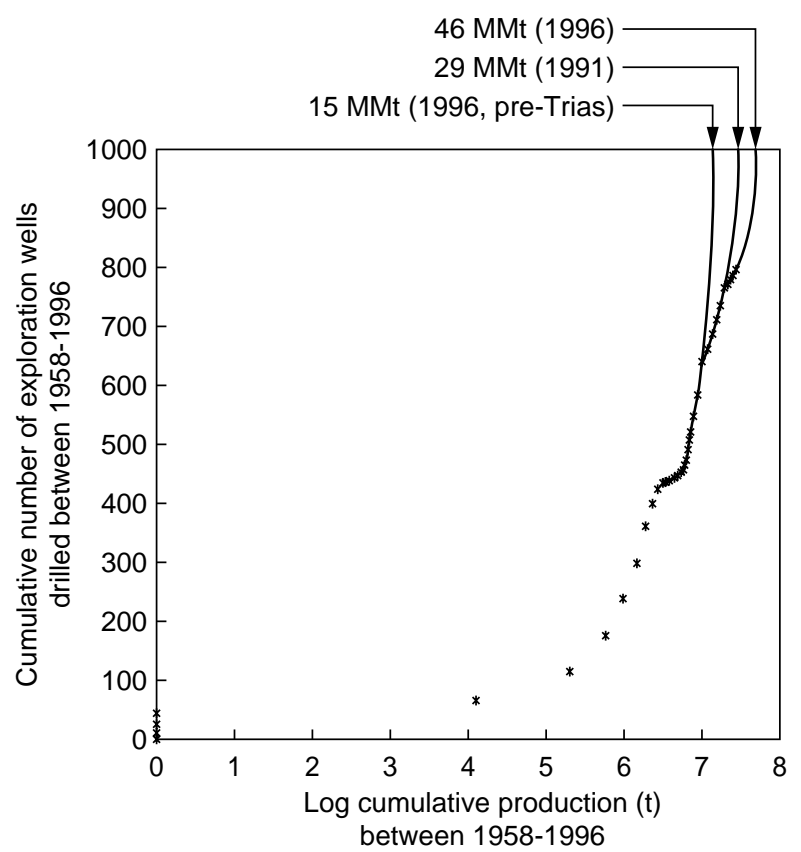

Figure 13

Total cumulative petroleum production in Paris Basin (creaming curve).

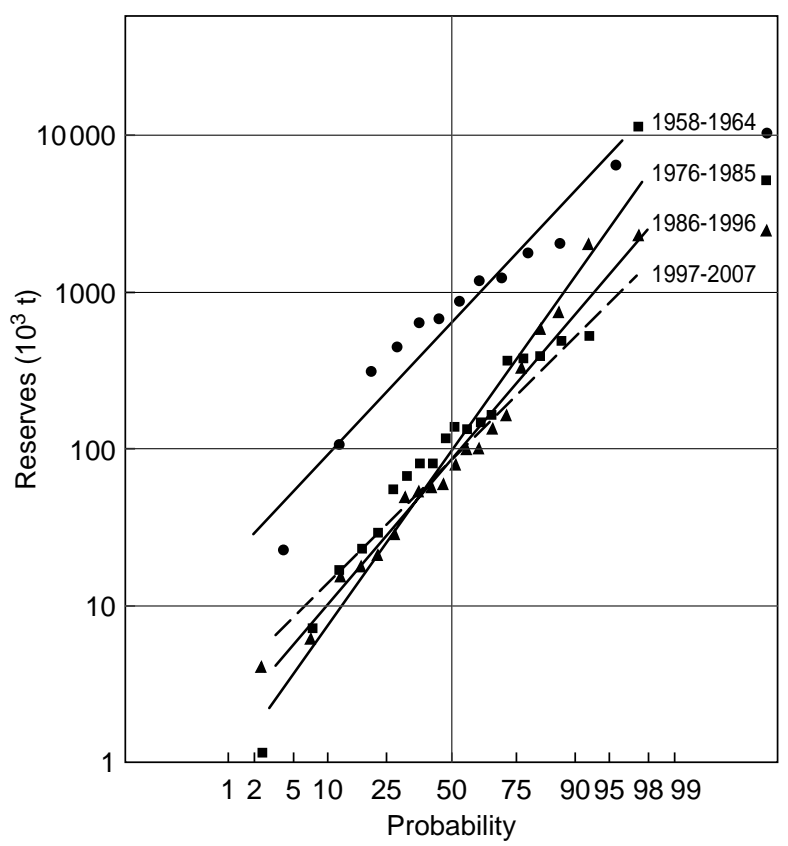

Figure 14

Field size distribution of Paris Basin separated by year of discovery. 
yielding a 5\% probability of a field size of more than $3 \mathrm{Mt}$. This is due to the Chaunoy field which pulls the distribution up to larger field sizes. The slope then falls back to its original value with a $5 \%$ probability of a field size bigger than $2 \mathrm{Mt}$. When extrapolating this trend over the following 10 years (1996-2006), 95\% of new discoveries will not be bigger than $900000 \mathrm{t}$.

\subsection{By Geological Formation}

Figure 15 repeats the previous procedure but this time separating field sizes by geological formation. The Dogger formation has the best field size distribution but the slope of its lognormal distribution is smaller than the one of the Triassic Keuper formation. For both formations, there is a $5 \%$ chance of finding a field that is bigger than $4 \mathrm{Mt}$. However, this value is probably smaller for future years for the same reasons as for the total Paris Basin.

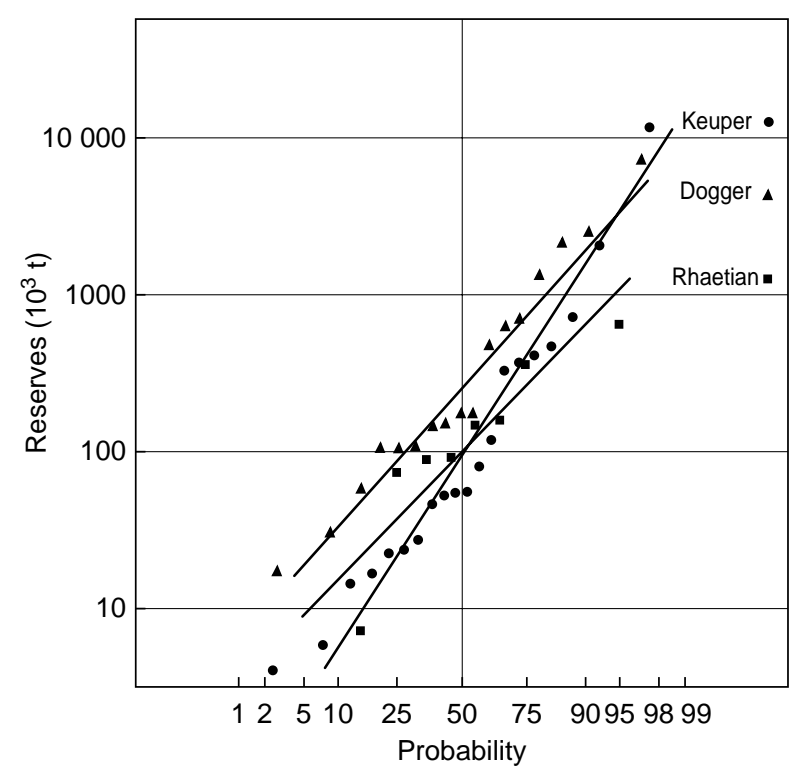

Figure 15

Field size distribution of Paris Basin separated by reservoir formation.

\section{SUCCESS RATIO}

The success ratio is the ratio of the number of commercial discoveries over the number of exploration wells that have reached their target. In the Paris Basin, this ratio increases almost linearly from 1/66 for the shallowest, the Cretaceous Neocomian formation that also had been drilled first, to $1 / 8$ in the deepest and latest to be drilled Triassic Keuper formation (Table 2). The evolution of the success ratio can be explained by the steadily increasing knowledge of the petroleum system of the Paris Basin, the increasing quantity and quality of available data, and by the fact that the Keuper formation is geologically and geographically closest to the Toarcian source rocks and therefore expelled petroleum has the shortest migration distance and smallest migration resistance.

TABLE 2

Exploration well statistics of Paris Basin

\begin{tabular}{l|c|c|c}
\hline & $\begin{array}{c}\text { Fields } \\
\text { discovered } \\
\text { since } 1958\end{array}$ & $\begin{array}{c}\text { Exploration wells } \\
\text { targeting } \\
\text { formation }\end{array}$ & $\begin{array}{c}\text { Success } \\
\text { ratio }\end{array}$ \\
\hline Neocomian & 4 & 264 & $1 / 66$ \\
Dogger & 17 & 640 & $1 / 37$ \\
Rhaetian & 10 & 157 & $1 / 16$ \\
Keuper & 20 & 160 & $1 / 8$ \\
\hline Total & 52 & 798 & $1 / 15$ \\
\hline
\end{tabular}

\section{CONCLUSIONS}

The relatively high sucess ratio of $1 / 8$ and a nonnegligable probability to discover a field of several million tons of petroleum makes the Triassic Keuper formation a good target for further exploration and potential additional reserves in the Paris Basin. Its success ratio is not only the highest of all producing formations (it is 8.3 times higher than the Cretaceous Neocomian and 4.6 times higher than the Jurassic Dogger reservoirs) but it is also the most realistic. Despite of its low value of $1 / 66$, the success ratio of the Cretaceous Neocomian is still too optimistic because it does not include wells that have targeted underlying formations but also encountered the Neocomian. In a similar way, the success ratios of the Jurassic Dogger and Triassic Rhaetian formations are overestimated.

The data analysis presented in this paper is based on known production data which do not take into account additional production gained by enhanced recovery methods or additional reserves added by discoveries based on new plays. A new play may indeed significantly increase reserves beyond the numbers obtained by our calculations as past experience in the Paris Basin has shown. Such new plays could be stratigraphic traps in pinch outs of the Keuper sandstones or targets deeper than the Triassic Keuper formation such as Middle Mesozoic Muschelkalk or Paleozoic Carboniferous reservoirs.

\section{ACKN OW LEDG EMEN TS}

The authors would like to thank J. Delmas from IFP and C. Ducreux from Beicip-Franlab for their help to 
prepare the data base and Y. Mathieu from IFP for his instructive comments.

\section{REFEREN CES}

Gaulier, J.M. and Burrus, J. (1994) Modeling Present and Past Thermal Regime in the Paris Basin: Petroleum Implications. EAGE Special Publications, 4, 61-73.

Harbaugh, J.W., Davis, J.C. and Wendebourg, J. (1995) Computing Risk for Oil Prospects, Pergamon Press, Oxford.
Lamiraux, C. and Mascle, A. (1998) Petroleum Exploration and Production in France. First Break, 16, 4, 109-116.

Perrodon, A. and Zabek, J. (1991) Interior Cratonic Basins. Analog Basins: Paris Basin. AAPG Memoir, 51, 663-679.

Weaver, O.D., Van Damme, A.M. and Calatayud, P. (1988) Oil and Gas Potential of France. Oil and Gas Journal, May 1988.

Final manuscript received in June 2002 